\title{
PENERAPAN METODE DEMONTRASI UNTUK MENINGKATKAN HASIL BELAJAR IPA SISWA KELAS IV SD NEGERI 005 SIMPANG RAYA KECAMATAN SINGINGI HILIR TAHUN PELAJARAN 2018/2019
}

\author{
TRI MULYATI \\ SD Negeri 005 Simpang Raya, Singingi Hilir \\ E-mail : trimulyati390@gmail.com
}

\begin{abstract}
ABSTRAK
Penelitian ini bertujuan untuk mengetahui apakah Penerapan Metode Demontrasi dalam proses belajar mengajar dapat meningkatkan hasil belajar siswa pada mata pelajaran IPA. Metode domonstrasi merupakan metode mengajar yang menyajikan bahan pelajaran dengan mempertunjukkan secara langsung objeknya atau caranya melakukan sesuatu untuk mempertunjukkan proses tertentu. Demonstrasi dapat digunakan pada semua mata pelajaran. Dalam pelaksanaan demonstrasi guru harus sudah yakin bahwa seluruh siswa dapat memperhatikan dan mengamati terhadap objek yang akan didemonstrasikan. Sebelumnya proses demonstrasi guru sudah mempersiapkan alat-alat yang digunakan dalam demonstrasi tersebut. Hasil Penelitian menunjukkan aktivitas guru pada siklus I mendapat skor 22, dan pada siklus II meningkat menjadi 27 ini menunjukkan bahwa aktivitas guru meningkat. Untuk aktivitas siswa pada siklus I adalah 78 dengan kategori tinggi dan pada siklus II meningkat menjadi 102 dengan kategori sangat tinggi. Dan mengenai hasil bealajar siswa pada siklus I rata-rata kelasnya adalah 75,65 dengan kategori tinggi pada siklus II meningkat menjadi 87,39 dengan kategori sangat tinggi. Dengan ini menandakan bahwa dengan Penerapan Metode Demontrasi dapat meningkatkan hasil belajar IPA siswa kelas IV SD Negeri 005 Simpang Raya Kecamatan Singingi Hilir Tahun Pelajaran 2018 / 2019.
\end{abstract}

Kata Kunci : Metode, Demontrasi, Hasil Belajar

\section{PENDAHULUAN}

Pendidikan adalah usaha sadar dan terencana untuk mewujudkan suasana belajar dan proses pembelajaran agar peserta didik secara aktif mengembangkan potensi dirinya untuk memiliki kekuatan spiritual keagamaan, pengendalian diri, kepribadaian, kecerdasan, akhlak mulia, serta ketrampilan yang dipelukan dirinya, Di sini siswa diharapkan dapat belajar secara aktif. Telah dicantumkan tadi bahwa belajar tidak hanya mencakup pengetahuan tetapi juga keterampilan (dalam pengertian luas yakni keterampilan untuk hidup/life skill), nilai dan sikap. Berkaitan dengan ini Trianto (2007) mendefinisikan belajar merupakan suatu proses yang kompleks dan unik.

Kompleks karena mengikat segala aspek kepribadian baik jasmani maupun rohani. Unik artinya tiap orang mempunyai cara belajar yang berbeda dengan yang lain yang disebabkan karena adanya perbedaan individual seperti minat, bakat, kemampuan, kecerdasan, serta tipe belajar. Hakikat perbuatan belajar adalah usaha terjadinya perubahan tingkah laku atau kepribadian bagi orang yang belajar. Perubahan itu baik dari aspek pengetahuan, ketrampilan, maupun sikap atau nilai. Sementara itu, agar proses belajar berlangsung efektif, semua faktor internal (dari dalam diri siswa) meliputi antara lain bakat, kecerdasan (intelektual, emosional, dan spiritual), minat, motivasi, sikap, dan faktor eksternal (dari luar diri siswa) meliputi antara lain tujuan pembelajaran, materi pelajaran, strategi dan metode pembelajaran, media pembelajaran/alat peraga, pengorganisasian kelas, reinforcement (penguatan), iklim sosial kelas, waktu yang tersedia, sistem, dan teknik evaluasi harus diperhatikan.

Berawal dari proses dan peningkatan mutu pendidikan, akhir-akhir ini telah berkembang berbagai metode/pendekatan pembelajaran yang tidak hanya mentransfer pengetahuan tetapi juga berusaha membangun struktur kognitif siswa. Pendekatan pembelajaran yang diadaptasikan 
dengan kemampuan siswa dalam proses pembelajarannya membangun struktuk kognitif siswa dan dapat memotivasi siswa untuk berfikir kritis dan kreatif.

Pada saat kegiatan pembelajaran berlangsung, tidak semua siswa mampu berkonsentrasi dalam waktu relatif lama atau menyerap semua pelajaran yang diberikan guru. Mereka saling terpengaruh dengan hal-hal sepele antara sesama siswa di dalam kelas. Guru harus mampu menarik perhatian siswa terhadap pembelajaran yang berlangsung, sehingga siswa mampu berperan aktif dalam proses pembelajaran agar tercapai hasil belajar yang optimal. Dalam proses pembelajaran IPA yang dilaksanakan di kelas IV SDN 005 Simpang Raya Kecamatan Singingi Hilir Kabupaten Kuantan singingi Tahun Ajaran 2018 / 2019, diperoleh informasi bahwa nilai hasil belajar peserta didik masih rendah. Dari 23 siswa, yang mendapat nilai di atas 70 hanya 9 siswa. Ini berarti bahwa hanya 39,13\% siswa yang mencapai kriteria ketuntasan belajar klasikal.

Dari kenyataan ini, Peneliti merasakan dan melihat siswa masih merasa kesulitan dalam penguasaian materi sehingga merasa perlu untuk segera menangani masalah tersebut. Salah satu solusi yang dapat dilakukan adalah dengan menggunakan metode pembelajaran yang tepat, diharapkan dapat meningkatkan penguasaan siswa terhadap materi yang dipelajari. Alasan dipilihnya metode Demontrasi ini yaitu karena metode ini mengajak siswa untuk berperan aktif dalam proses pembelajaran sehingga banyak membantu siswa dalam pemahaman materi pembelajaran.

Secara sederhana dapat dikatakan bahwa metode adalah suatu cara dalam fungsinya merupakan alat untuk mencapaai tujuan. Winarno Surakhmad dalam Fitri Yani (2006:13) menyatakan bahwa metode adalah alat untuk mencapai tujuan ". ( Fitri Yani, 2006:13 ). Sementara itu kamus besar Bahasa Indonesia mengatakan metode adalah cara yang teratur dan terpikirkan baik-baik untuk mencapaai maksud ( dalam ilmu pengetahuan dan sebagainya). Metode adalah cara guru menyampaikanmateri pelajaran kepada siswa untuk mencapai tujuan tertentu. (Depdiknas : 2003). Jadi dalam proses kegiatan pembelajaran seorang guru tidak dapat lepas dari metode, karena apapun cara yang digunakan oleh guru dalam menyampaikan meteri pembelajaran dalah merupakan metode.

Disamping itu Hadari Nawawi mengatakan: "Metode mengajar adalah kesatuan langkah kerja yang dikembangkan oleh guru berdasarkan pertimbangan rasional tertentu, masing-masing jenis bercorak khas dan kesemuanya berguna untuk mencapai tujuan pengajaran tertentu "Bertitik dari beberapa pengertian metode tersebut, sekurangnya ada tiga hal penting dalam metode yaitu : (1) Metode adalah cara yang teratur dan terpikirkan baik-baik. (2) Metode adalah suatu cara untuk mencapai tujuan. (3) Metode adalah cara yang digunakan oleh guru dalam mengajar untuk menyampaikanbahan pengajaran yang direncanakan secara menyeluruh dengan urutan yang sistematis dan berdasarkan pendekatan tertentu. Dengan demikian penulis mencoba menyimpulkan bahwa metode pengajaran adalah suatu cara yang teratur dan terpikirkan baik-baik yang digunakan guru untuk menyampaikan bahan pengajaran dengan perencanaan secara menyeluruh, sistematis dan berdasarkan pendekatan tertentu untuk mencapai tujuan yang seoptimal mungkin.

Berdasarkan kesimpulan diatas, maka semakin baik sebuaah metode, semakin efektif pula pencapaian tujuan. Istilah demonstrasi dalam pengajaran dipakai untuk menggambarkan suatu cara mengajar yang pada umumnya penjelasan verbal dengan suatu kerja fisik atau pengoperasioan peralatan baran gatau benda. Kerja fisik itu telah dilakukan atau peralatan itu telah dicoba lebih dahulu sebelum didemonstrasikan. Orang yang mengdemosntasikan (guru, peserta didik, atau orang luar) mempertunjukkan sambil menjelaskan tentang sesuatu yang didemonstrasikan (Ramayulis:2004).

Ibrahim (2003:106-107) menyatakan metode yang biasa digunakan dalam kegiatan belajar mengajar antara lain : metode ceramah, metode tanya jawab, metode diskusi, metode demonstrasi, metode eksperimen, metode pemberian tugas, metode karyawisata, metode sosiodrama dan lainlain. 
Demontrasi adalah cara penyajian bahan pelajaran dengan memperagakan atau mempertunjukkan kepada semua siswa suatu proses, situasi, atau benda tertentu yang sedang di pelajari baik sebenarnya atau tiruan, yang di sertakan dengan penjelasan lisan. (Sudirman:1988).Metode domonstrasi merupakan metode mengajar yang menyajikan bahan pelajaran dengan mempertunjukkan secara langsung objeknya atau caranya melakukan sesuatu untuk mempertunjukkan proses tertentu. Menurut Daryanto (2009:403), metode demonstrasi adalah cara menyajikan bahan pembelajaran dengan menampilkan atau memperagakan kepada peserta didik yang sering disertai penjelasan secara lisan. Dan menurut Rusminiati (2007: 2) metode demonstrasi merupakan peragaan pada suatu peristiwa, maupun tingkah laku yang dicontohkan supaya peserta didik atau siswa dalam suatu kelas dapat memahami dengan mudah. Sedang menurut Roestiyah, N (2008: 80), menjelaskan bahwa metode demonstrasi adalah salah satu metode mengajar dimana guru atau narasumber menunjukkan atau memperagakan suatu proses kepada peserta didik atau sisiwa. Demonstrasi dapat digunakan pada semua mata pelajaran. Dalam pelaksanaan demonstrasi guru harus sudah yakin bahwa seluruh siswa dapat memperhatikan dan mengamati terhadap objek yang akan didemonstrasikan. Sebelumnya proses demonstrasi guru sudah mempersiapkan alat - alat yang digunakan dalam demonstrasi tersebut.

Karakteristik, Pengalaman Belajar, Keunggulan, dan Ketrampilan Metode Demonstrasi :

Tabel 1. Hubungan Karakteristik Metode Demontrasi dengan Pengalaman Belajar Siswa

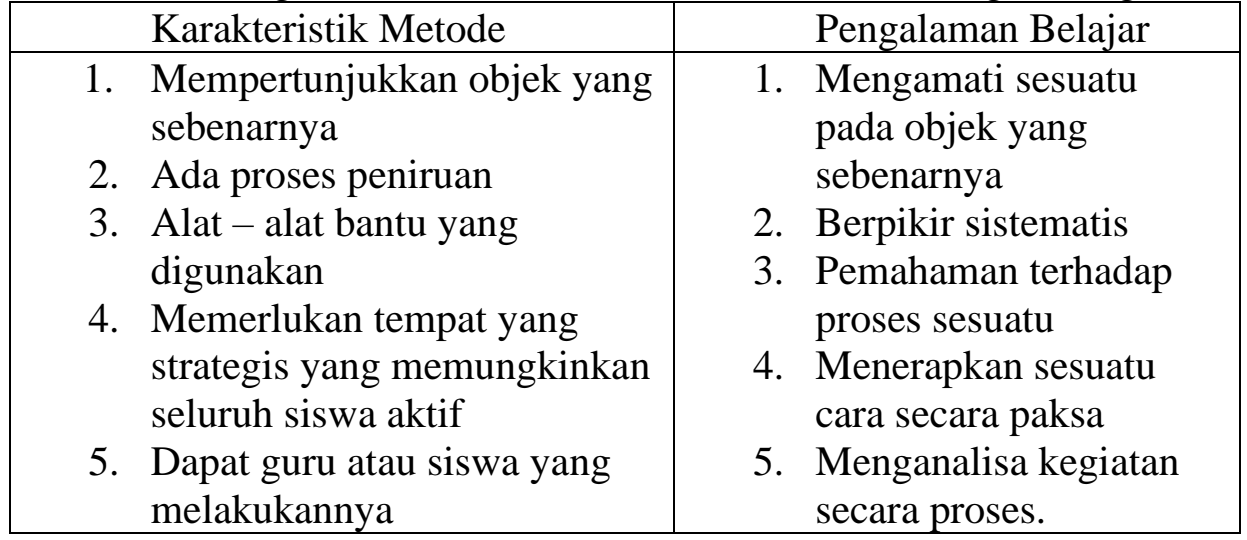

Kebaikan Metode Demonstrasi adalah 1). Keaktifan peserta didik akan bertambah, lebih-lebih kalau peserta didik diikut sertakan. 2). Pengalaman peserta didik bertambah karena peserta didik turut membantu pelaksanaan suatu demonstrasi sehingga ia menerima pengalaman yang bisa mengembangkan kecakapannya. 3). Pelajaran yang diberikan lebih tahan lama. Dalam suatu demonstrasi, peserta didik bukan saja mendengar suatu uraian yang diberikan oleh guru tetapi juga memperhatikannya bahkan turut serta dalam pelaksanaan suatu demonstrasi .4). Pengertian lebih cepat dicapai. Peserta didik dalam menanggapai suatu proses adalah dengan mempergunakan alat pendengar, penglihat, dan bahkan dengan perbuatannya sehingga memudahkan pemahaman peserta didik dan menghilangkan sifat verbalisme dalam belajar. 5). Perhatian peserta didik dapat dipusatkan dan titik yang yang dianggap penting oleh guru dapat diamati oleh peserta didik seperlunya. Sewaktu demonstrasi perhatian peserta didik hanya tertuju kepada suatu yang didemonstrasikan sebab peserta didik lebih banyak diajak mengamati proses yang sedang berlangsung dari pada hanya semata-mata mendengar saja. 6). Mengurangi kesalahan-kesalahan. Penjelasan secara lisan banyak menimbulkan salah paham atau salah tafsir dari peserta didik apalagi kalau penjelasan tentang suatu proses. Tetapi dalam demonstrasi, disamping penjelasan lisan juga dapat memberikan gambaran konkrit. 7). Beberapa masalah yang menimbulkan petanyaan atau masalah dalam diri peserta didik dapat terjawab pada waktu peserta didik mengamai proses demonstrasi. 8). Menghindari "coba-coba dan gagal" yang banyak memakan waktu belajar, di samping praktis dan fungsional. Khususnya bagi peserta didik yang ingin berusaha mengamati 
secara lengkap dan teliti atau jalannya sesuatu. Sedang Kelemahan Metode Demonstrasi adalah: 1). Metode ini membutuhkan kemampuan yang optimal dari pendidikan untuk itu perlu persiapan yang matang. 2). Sulit dilaksanakan kalau tidak ditunjang oleh tempat, waktu dan peralatan.

\section{METODE PENELITIAN}

Penelitian ini menggunakan metode Penilitian Tindakan Kelas (PTK). Dalam melaksanakan penelitian ini Penulis menggukan dua siklus yang mana masing masing siklus denga satu kali pertemuan. Setiap siklus melalui tahapan tahapan yaitu tahap Perencanaan dimana pada tahap ini penulis membuat suatu perencanaan yang meliputi, menentukan supervisornya, lembar observasi, lembar evaluasi, Rencana Persiapan Pembelajaran (RPP), Tahap Pelaksanaan Tindakan, pada tahap ini penulis melaksanakan Pembelajaran sesuari perencanaan yang telah dibuat, dan selama pelaksanaan pembelajaran ini penulis diamati oleh seorang supervisor dengan mengisi lembar observasi, kemudian setelah selesai diadakan refleksi dan siskusi bersama supervisor untuk mengetahui dimana letak kelemahan dan kekurangannya kemudian dicari solusinya. Yang menjadi populasi dalam penelitihan ini adalah seluruh siswa kelas IV SD Negeri 005 Simpang Raya yang Bejumlah 23 orang siswa terdiri dari siswa 12 orang siswa laki-laki dan 11 orang siswa perempuan.

Pada penelitihan ini data yang dianalisis adalah 1. hasil belajar siswa. Data hasil belajar diperoleh dari tes tulis yang diadakan pada akhir masing masing siklus. 2. Aktivis Siswa, aktivitas siswa ini diperoleh dari hasil pengamatan yang dilaksanakan oleh supervir selama prosesn pembelajaran dilaksanakan penulis dengan mengisi lembar observasi. 3. Aktivitas guru, sebagaimana aktivitas siswa, aktivitas guru juga diamati oleh supervisor dengan mengisi lembar observasi.

\section{HASIL DAN PEMBAHASAN}

Penelitian Tindakan Kelas yang dilaksanakan dengan "Penerapan Metode Demontrasi ini dilaksanakan di kelas IV SD Negeri 005 Simpang Raya Kecamatan Singingi Hilar dengan murid sebanyak 23 orang siswa dengan perincian 12 orang siswa laki-laki dan 11 orang siswa perempuan".

Penelitian Tindakan Kelas perbaikan pembelajaran ini dilaksanakan dalam dua siklus yaitu siklus I dan siklus II, dimulai dengan membuat suatu perencanaan, yaitu kegiatan menentukan jadwal pelaksanaan, menentukan supervisor, Menyusun Rencana Perbaikan Pembelajaran, menyiapkan lembar observasi untuk kegiatan siswa dan guru, menentukan alat untuk evaluasi dan daftar nilai siswa. Setelah semua perencanaan dirasa cukup, baru di mulai pelaksaan perbaikan pembelajaran.

Pembelajaran dimulai dengan mengatur tempat duduk siswa agar siap menerima pelajaran baik secara fisik maupun psikis dengan mengajak berdo'a, mengecek kehadiran siswa, memberikan motivasi dengan mengajak anak untuk bernyanyi biar keadaan siswa menjadi senang kemudian diadakan tanya jawab tentang materi pembelajaran yangsudah diajarkan, menyampaikan tujuan pembelajaran dan memasang alat peraga tentang ganbar-gambar penampakan bumi, kemudian guru mendemontrasikan tentang kenampakan bumi serta segala sesuatu yang berkaitan denga penampakan bumi., Kemudian guru mengorganisasikan siswa dalam kelompok-kelompok kecil untuk mengerjakan tugas. Guru memberikan tugas untuk didiskusikan dalam kelompoknya. Selama siswa melakukan diskusi guru berkeliling untuk memberikan bimbingan kpada kelompok yang memerlukan bimbingan dan setelah diskusi selesai guru meminta perwakilan kelompok untuk mempersentasikan hasilnya diskusinya dan kelompok lain menanggapinya.. Guru memberikan penguatan dari hasil diskusi yang telah dipersentasikan dan dari tanggapan kelompok yang alain. Kemudian guru memberikan soal latihan untuk mengetahui sejauh mana materi yang telah diberikan dikuasai oleh siswa. 
Dari hasil tes yang telah dilaksanakan pada proses pembelajaran dengan penerapan metode demontrisi ini diperoleh hasil sebagaimana yang ditampilkan pada tabel berikut:

Tabel 2. Rekap Hasil Nilai Ilmu Pengetahuan Alam Siswa Kelas IV SD Negeri 005 Simpang Raya dengan Penerapan Metode Demontrasi Pada Siklus I dan Siklus II Tahun Pembelajaran 2018/2019

\begin{tabular}{|c|c|c|c|c|c|}
\hline \multirow{3}{*}{$\begin{array}{l}\text { Rentang } \\
\text { Nilai }\end{array}$} & \multirow{3}{*}{ Kategori } & \multicolumn{3}{|c|}{ Frekuensi / Persentase } & \multirow{3}{*}{ Ket } \\
\hline & & \multirow{2}{*}{$\begin{array}{l}\text { Sebelum } \\
\text { Perbaikan }\end{array}$} & \multicolumn{2}{|l|}{ Sklus } & \\
\hline & & & Siklus 1 & Siklus 2 & \\
\hline $90-100$ & Sangat baik sekali & 4 & 8 & 15 & Tuntas \\
\hline $80-89$ & Baik sekali & 2 & 4 & 3 & Tuntas \\
\hline $70-79$ & Baik & 3 & 4 & 4 & Tuntas \\
\hline $60-69$ & Cukup & 8 & 5 & 1 & T.Tuntas \\
\hline $50-59$ & Kurang & - & - & - & T.Tuntas \\
\hline$<50$ & Sangat kurang & 6 & 2 & - & T.Tuntas \\
\hline \multicolumn{2}{|c|}{ Jumlah Yang Tuntas } & 9 & 16 & 22 & \\
\hline \multicolumn{2}{|c|}{ Jumlah Tidak Tuntas } & 14 & 7 & 1 & \\
\hline \multicolumn{2}{|c|}{ Rata-rata kelas } & 63,41 & 75,65 & 87,39 & \\
\hline \multicolumn{2}{|c|}{ Prosentase Ketuntasan } & $39,13 \%$ & $69,57 \%$ & $95.65 \%$ & \\
\hline
\end{tabular}

Berdasarkan tabel rekapitulasi hasil belajar diatas dapat dilihat bahwa nilai belajar siswa pada mata pelajaran Ilmu Pengetahuan Alam sebelum pelaksanaan perbaikan pembelajaran siswa yang mencapai KKM hanya 9 orang siswa $(39,13 \%)$ dari 23 orang siswa. Berdasarkan kenyataan ini peneliti mengadakan perbaikan pembelajaran untuk memperbaiki hasil bejaran siswa dan meningkatkan motivasi belajar siswa. Ternyata setelah diadakan perbaikan pembelajaran oleh peneliti pada siklus pertama ini siswa yang mencapai ketuntasan bertambah menjadi 16 orang siswa atau 69,57\% dan masih terdapat 7 orang siswa yang belum mencapai ketuntasan. berdasarkan hasil pembahasan peneliti dan supervisor terhadap proses perbaikan pembelajaran pada siklus I, ada beberapa kelemahan dalam pelaksanaan pembelajaran diantaranya : 1 . Pengelolaan pembelajaran oleh peneliti telah dijalankan sesuai dengan tahapan-tahapan yang dimuat dalam Rencana Perbaikan Pembelajaran. Namun dalam penerapan Metode Demontrasi dalam proses pembelajaran guru masih mengalami beberapa kekurangan, dalam semua aspek kegiatan, hanya dalam hal menata fasilitas saja yang dilaksanakan sangat baik. 2. Motivasi dan keseriusan siswa dalam mengikuti pembelajaran belum optimal. 3. Siswa masih kurang berani mananyakan kesulitannya kepada guru dan kurang aktif dalam .kerja kelompok.

Semua kekurangan selama pelaksanaan perbaikan pembelajaran pada siklus I ini di konsultasikan dan di diskusikan dengan supervisor untuk mencari solusi agar kekurang tersebut dapat diperbaiki dan tidak lagi terjadi pada siklus selanjutnya. Dan berbekal dari saran dan hasil diskusi dengan supervisor, pelaksanaan perbaikan pembelajaran pada siklus II ini semua kekurangan dan kelemahan kelemahan yang terjadi pada siklus pertama tidak terulang Kembali, dengan semakin membaiknya pelaksanaan perbaikan pembelajaran pada siklus ini mengakibatkan siswa yang mencapai Kriteria Ketuntasan Minimal miningkat menjadi 22 orang siswa (95,65\%), sehingga hanya tinggal 1 orang siswa $(4.35 \%)$ yang belum tuntas. Ini menunjukkan bahwa Penerapan Metode Demontrasi dalam proses pelaksanaan pembelajaran dapat mempengaruhi keberhasilan belajar siswa, karena dengan Metode Domentrasi ini dalam prose pembelajaran siswa ikut terlibat langsung dalam proses belajar sehingga siswa merasa senang dan termotivasi yang 
akhirnya dengan Penerapan Metode Demontrasi dapat meningkatkan hasil belajar siswa. Hasil belajar siswa tersebut bila ditampilkan dalam bentuk grafik akan tampak sebagai berikut:

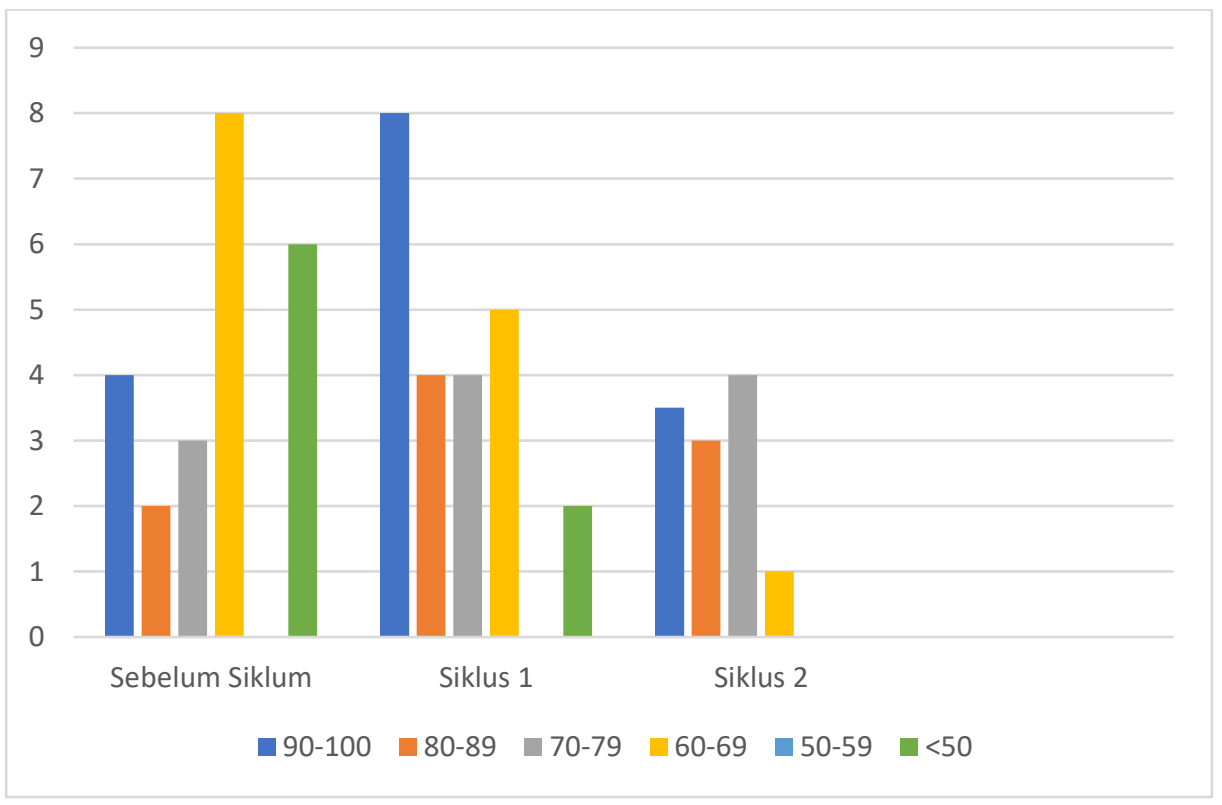

Gambar 1. Grafik Hasil Belajar Ilmu Pengetahuan Alam Siswa Kelas IV SD Negeri 005 Simpang Raya dengan Penerapan Metode Demontrasi.

Hasil belajar siswa dalam pelaksanaan perbaikan pembelajaran ini bila kita bandingkan dengan hasil belajar siswa yang peneliti laksanakan sebelumnya mengalami peningkatan lebih baik lagi. Sebelum pelaksanaan perbaikan pembelajaran ini, peneliti pernah melaksakan pembelajaran dengan metode yang sama yaitu metode Demontrasi yang mana hasilnya sebagai berikut :

Tabel 3. Rekap Hasil Nilai Ilmu Pengetahuan Alam Siswa Kelas IV SD Negeri 005 Simpang Raya dengan Penerapan Metode Demontrasi Pada Siklus I dan Siklus II

Tahun Pembelajaran 2017/2018

\begin{tabular}{|c|c|c|c|c|c|}
\hline \multirow{3}{*}{$\begin{array}{l}\text { Rentang } \\
\text { Nilai }\end{array}$} & \multirow{3}{*}{ Kategori } & \multicolumn{3}{|c|}{ Frekuensi / Persentase } & \multirow{3}{*}{ Ket } \\
\hline & & \multirow{2}{*}{$\begin{array}{l}\text { Sebelum } \\
\text { Perbaikan }\end{array}$} & \multicolumn{2}{|l|}{ Sklus } & \\
\hline & & & $\begin{array}{l}\text { Siklus } \\
1\end{array}$ & Siklus 2 & \\
\hline $90-100$ & Sangat baik sekali & & 2 & 4 & Tuntas \\
\hline $80-89$ & Baik sekali & 2 & 5 & 6 & Tuntas \\
\hline $70-79$ & Baik & 4 & 4 & 5 & Tuntas \\
\hline $60-69$ & Cukup & 9 & 6 & 4 & T.Tuntas \\
\hline $50-59$ & Kurang & - & 2 & 1 & T.Tuntas \\
\hline$<50$ & Sangat kurang & 5 & 1 & - & T.Tuntas \\
\hline \multicolumn{2}{|c|}{ Jumlah Yang Tuntas } & 6 & 11 & 15 & \\
\hline \multicolumn{2}{|c|}{ Jumlah Tidak Tuntas } & 14 & 9 & 5 & \\
\hline \multicolumn{2}{|c|}{ Rata-rata kelas } & 59 & 68,8 & 75 & \\
\hline \multicolumn{2}{|c|}{ Prosentase Ketuntasan } & $30 \%$ & $55 \%$ & $75 \%$ & \\
\hline
\end{tabular}


Dari perbandingan pelaksanaan pembelajaran yang peneliti laksanakan dengan pelaksanaan pembelajaran sebelumnya dengan metode yang sama, hasil belajar mengalami peningkatan, yaitu secara keseluruhan hasil belajar sebelumnya ketuntasannya hanya mencapai $75 \%$ sedang pada pembelajaran saat ini mencapai 95,65\%. Ini menunjukkan bahwa Metode Demontrasi bila sering dilaksanakan hasil belajar siswa akan selalu mingkat.

Untuk aktivitas siswa menurut observasi secara umum sudah menunjukkan minatnya untuk belajar namun masih tedapat siswa yang kurang kurang serius terhadap belajarnya. Dan untuk mengetahui rata-rata aktivitas siswa dalam penerapan Metode Demontrasi dapat dilihat pada tabel berikut :

Tabel 3. Rekapitulasi aktivitas belajar siswa kelas V SD IV SD Negeri 005 Simpang Raya dengan Penerapan Metode Demontrasi Pada Siklus I dan Siklus II

\begin{tabular}{|c|c|c|c|c|c|}
\hline \multirow{2}{*}{ No } & \multirow{2}{*}{ Aktivitas yang Diamati } & \multicolumn{2}{|c|}{ Siklus I } & \multicolumn{2}{|c|}{ Siklus II } \\
\hline & & Aktivitas & $\%$ & Aktivitas & $\%$ \\
\hline 1 & $\begin{array}{l}\text { Mendengarkan penjelasa guru } \\
\text { dengan serius }\end{array}$ & 18 & $78,26 \%$ & 23 & $96 \%$ \\
\hline 2 & Mencatat penjelasan guru & 15 & $65,22 \%$ & 19 & $79 \%$ \\
\hline 3 & Menanyakan kesulitan & 13 & $56,52 \%$ & 21 & $88 \%$ \\
\hline 4 & Aktif dalam kelompok & 14 & $60,87 \%$ & 20 & $83 \%$ \\
\hline 5 & $\begin{array}{l}\text { Melaksanakan tugas dengan } \\
\text { tekun }\end{array}$ & 18 & $78,26 \%$ & 22 & $92 \%$ \\
\hline & Jumlah aktivitas siswa & 81 & & 105 & \\
\hline & nlah rata-rata aktivitas siswa & & $67,83 \%$ & & $88 \%$ \\
\hline
\end{tabular}

Berdasarkan hasil pengamatan Supervisor melalui lembar pengamatan aktivitas siswa menunjukkan bahwa masih adanya kelemahan kelemahan yang mengakibatkan aktivitas siswa pada siklus pertama ini belum maksimal, hanya mencapai skor 81 dari total skor tertinggi 115 . Dan setelah berdiskusi dengan Supervisor serta memdapat saran dari Supervisor kekurangan dan kelemahan yang terjadi pada siklus ke pertama dapat diatasi dan ditingkatkan lagi pada pelaksanaan perbaikan pembelajran pada siklus kedua, hal ini tampak pada lembar pengamatan aktivitas siswa yang diisi oleh Supervisor telah menunjukkan peningkatan aktivitas siswa pada semua aspek. Dan secara keseluruhan sudah mencapai skor 105 dari skor tertinggi 115 berarti dari siklus pertama sampai siklus kedua mengalami peningkatan 24 skor.

Untuk aktivitas guru berdasarkan hasil pengamatan Supervisor, dalam penerapan Metode Demontrasi secara umum guru sudah melaksanakan dengan tahapan tahapan pembelajaran dengan "Baik". Data hasil observasi Aktivitas guru dalam proses belajar mengajar dengan penerapan metode Demontrasi dapat dilihat pada tabel Berikut : 
Tabel 4. Aktivitas Guru

\begin{tabular}{|l|l|l|l|l|l|}
\hline \multirow{2}{*}{ No } & \multirow{2}{*}{ Pelaksanaan Aktivitas } & \multicolumn{2}{|l|}{ Siklus 1 } & \multicolumn{2}{l|}{ Siklus 2 } \\
\cline { 3 - 6 } & & Jumlah & Skor & Jumlah & Skor \\
\hline 1 & Sangat baik & 1 & 4 & 6 & 24 \\
\hline 2 & Baik & 6 & 18 & 1 & 3 \\
\hline 3 & Cukup & - & & - & - \\
\hline 4 & Tidak dilaksanakan & - & - & - & - \\
\hline \multicolumn{2}{|l|}{ Jumlah } & & & & \\
\hline
\end{tabular}

Dari tabel diatas dapat diperoleh gambaran tentang aktivitas guru dalam melaksanakan perbaikan pembelajaran sebagai berikut:

Pelaksanaan proses pembelajaran yang dilakukan oleh peneliti dari mulai siklus I sampai siklus II aktiviatas guru selalu meningkat, karena kekurangan-kekurangan yang terjadi pada pelaksanaan perbaikan pembelajaran selalu direfleksi dan di diskusikan oleh supervisor dan dicari solusi perbaikannya. Sehingga semua kesalahan dan kekurangannya yang terjadi pada siklus pertama dapat diperbaiki pada pelaksanaan siklus kedua, sehingga kekurangan-kekurangan tersebut tidak terulang lagi pada pelaksanaan siklus kedua.

\section{KESIMPULAN}

Dalam pelaksanaan perbaikan pembelajaran Ilmu Pengetahuan Alam tentang Kenampakan Bumi, Bintang dan Bulan dengan menerapkan metode Demontrasi dapat memotivasi siswa untuk berperan aktif dalam proses pembelajaran yang akhirnya dapat meningkatkan hasil belajar siswa atau peningkatan penguasaan terhadap materi pembelajaran Ilmu Pengetahuan Alam di Kelas IV SD Negeri 005 Simpang Raya Kecamatan Singingi Hilir. Peningkatan penguasaan materi atau hasil belajar siswa ini dapat dilihat : (1) Dari hasil belajar Nampak adanya peningkatan, sebelum perbaikan rata-rata kelasnya hanya 63,91 Setelah diadakan perbaikan mengalami peningkatan yaitu pada siklus I mencapai 75,65 dan pada siklus II menjadi 87,39. (2) Dilihat dari ketuntasan belajar, sebelum pelaksanaan perbaikan pembelajaran siswa yang tuntas hanya 9 orang atau 39,13\% setelah diadakan perbaikan pada siklus I siswa yang tuntas 16 orang atau $69.57 \%$ dan pada siklus II yang tuntas mencapai 22 orang atau 95,65\%. (3) Aktivitas siswa juga mengalami peningkatan pada siklus I mencapai skor 81 dan siklus II meningkat menjadi 102 Dari total skor 115. (4) Dan aktivitas guru pun juga mengalami peningkatan yaitu pada siklus I mencapai skor 22 dan pada siklus II mencapai skor 27 dari jumlah skor 28. Dengan demikian penerapan metode Demontrasi ini tidak hanya meningkatkan hasil belajar siswa, meningkatkan ketuntasan dan aktivitas siswa, tetapi juga meningkatkan kemampuan guru dalam menerapkan suatu metode pembelajaran khususnya metode Demontrasi. Disamping itu metode demontrasi ini bila sering diterapkan akan meningkatkan motivasi belajar siswa yang akhirnya juga akan meningkatkan hasil belajar siswa.

\section{DAFTAR PUSTAKA}

Ali, Muhammad. (1996). Guru Dalam Proses Belajar Mengajar. Bandung: Sinar Baru Algesindon. A. Syaiful, (2003), Proses Belajar Mengajar, Bandung, Remaja Rosdakarya

Daryanto.(2009). Demonstrasi Sebagai Metode Belajar. Jakarta: Depdikbud.

Dekdiknas, (2003). Undang-Undang Sistem Pendidikan Nasional, Jakarta, Balitbang.

Fitri Yanti, (2006). Pengaruh Metode Role Playing Terhadap Hasil BelajarPendidikan oral Pancasila Siswa di SMA 1 Siak Hulu, Kampar

Hadari Nawawi, (2003), Proses Belajar Mengajar, Jakart. Bumu Aksara. Hamalik, (2007). Proses Belajar Mengajar, Jakarta. Bumi Aksara 
Ibrahim R dan Nana Syaodih, (2003), Perencanaan Pengajaran, Jakarta, Rineka Cipta.

Jayus, (2008), Penggunaan Model Pembelajaran STAD Untuk Menngkatkan Hasil Belajar Siswa Kelas VI SD Negeri 014 Suka Maju Kecamatan Singingi Hilir

Ramayulis, (2004). Metodologi Pendidikan Agama Islam. Jakarta: Kalam Mulia

Roestiyah N. (2008). Strategi Belajar Mengajar. Jakarta: Rineka Cipta.

Rusminiati. (2007). Pengembangan Pendidikan Kewarganegaraan SD. Jakarta: Depdiknas

Sardiman, A.M. (1996). Interaksi dan Motivasi Belajar Mengajar. Jakarta: Bina Aksara.

Syah Muhibin, (1997). Spikologi Pendidikan dengan Pendekatan Baru, Bandung.

Trianto, (2007), Model Model Pembelajaran Inovatif Berorientasi Konstruktivistik, Surabaya, PT. Prestasi Pustaka 